UNDERGRADUATE RESEARCH IN NATURAL AND CLINICAL SCIENCE AND TECHNOLOGY (URNCST) JOURNAL Read more URNCST Journal articles and submit your own today at: https://www.urncst.com

\title{
The 2nd Annual McMaster Energy Week: Energy Nexus Competition
}

Damien Joseph, B.Sc Student [1]*, Hanu Chaudhari, B.HSc Student [1], Ryan Rogers, B.Eng.Mgmt [1,2], Folarin Ologunagba, B.Eng Student [1], Maisha Ahmed, B.Sc Student [1]

[1] McMaster University, Hamilton, Ontario, Canada

[2] McMaster Institute for Energy Studies, Hamilton, Ontario, Canada

*Corresponding Author: josepd4@mcmaster.ca

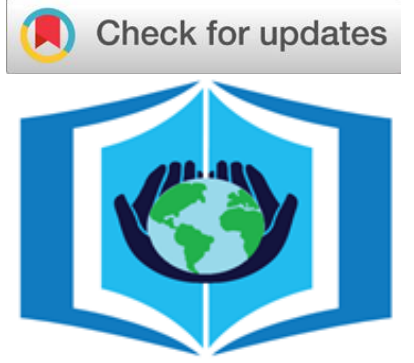

URNCST Journal

"Research in Earnest"

\begin{abstract}
The following abstracts were produced by delegates selected for the Energy Nexus Competition taking place during the 2nd annual McMaster Energy Week. The first three abstracts were selected as the winners of the competition, reported here in order of 1st place to 3rd. McMaster Energy Week is Canada's first student-led energy week that aims to take the complex and multifaceted issue of climate change and present solutions towards building Canada's sustainable future. We are bringing together academia, industry, government, communities, and students to further the dialogue on Canadian environment and energy. For more information on this visit https://www.mcmasterenergyweek.com/ or email chair@ mcmasterenergyweek.com.
\end{abstract}

Keywords: keyword1; keyword2; keyword3

Table of Contents

Abstracts from Written Reports

pg. A01-A05

\section{Conference Abstracts}

Note: These abstracts have been reproduced directly from the material supplied by the authors, without editorial alteration by the staff of the URNCST Journal. Insufficiencies of preparation, grammar, spelling, style, syntax, and usage are the authors.

\section{Abstracts from Written Reports}

Incentivizing local food production using sustainable tax policies Natalie Ciancone, B.Eng Student [1], Bri Conn, B.Eng Student [2], Desmond Kennedy, B.Eng Student [2], Erin Nunn, B.Eng Student [2], Keara Wilson, B.Eng Student [2]

[1] Department of Civil Engineering, McMaster University, Hamilton, Ontario, Canada L8S 4L8

[2] Department of Engineering Physics, McMaster University, Hamilton, Ontario, Canada L8S 4L8

In order to reduce the greenhouse gas emissions relating to food transportation and production, a local agriculture solution for a Canadian community of 200,000 is proposed. By implementing a sustainable tax policy on all food items purchased within this community, revenue can be generated in order to fund a series of greenhouses which will make use of hydroponics and urban agricultural practices to grow produce including tomatoes, lettuce, and potatoes. The aforementioned tax policy will evaluate the distance which a food was imported from, as well as the emissions involved in its production, in order to add a tax equating to $\$ 10 /$ tonne of $\mathrm{CO} 2 \mathrm{e}$ emitted. Anticipated tax revenue is roughly $\$ 14 /$ person/year which totals to over $\$ 2$ million/year to fund the greenhouses. The goal of the taxation policy is not only to generate the capital needed for the greenhouses project, but also to make consumers aware of the impacts their food choice habits have, which will hopefully lead to a reduction in the consumption of high-emission foods, as well as imported produce. By eliminating the need for sourcing produce from distant areas, this policy and project will work together to add resilience to the community's nexus resources. 
UNDERGRADUATE RESEARCH IN NATURAL AND CLINICAL SCIENCE AND TECHNOLOGY (URNCST) JOURNAL Read more URNCST Journal articles and submit your own today at: https://www.urncst.com

Diversification of the transportation industry through electric vehicle incentivization and alternative fuel generation Jenny Chen, B.Eng Student [1], Deniz, Koc, B.Eng Student [1], Melissa Larocque, B.Eng Student [2], Abhishek Premachandra, B.Eng Student [2], Alexandra Szewczyk, B.Eng Student [2] [1]Department of Chemical Engineering, McMaster University, Hamilton, Ontario, Canada L8S 4L8

[2] Department of Chemical and Bioengineering, McMaster University, Hamilton, Ontario, Canada L8S 4L8

Significant reductions in greenhouse gases is required from all public and private sectors for Canada to achieve the Paris Agreement target of reducing emissions by $80 \%$ relative to 2005 levels. Transportation and private vehicle use contributes significantly to these emissions; data for a reference city with a population of $\sim 200,000$ people indicated that transportation accounts for $31 \%$ of emissions, with $94 \%$ being due to private vehicle use. This report outlines a systematic incentivization program that facilitates a gradual shift from gasoline to electric vehicles in private vehicle ownership. The current state of EV prevents the technology from entering the freighting and public transit industry due to limitations in charge times and battery weights. As such, a multi-sectoral solution is proposed where food and human waste produced by households, businesses and municipal buildings will be collected and processed to produce dimethyl ether, a direct substitute for diesel that utilizes existing engines and produces $30 \%$ less $\mathrm{CO} 2$ than diesel. Based on projected population growth and the efficiency of incentivization programs to promote the purchasing of $\mathrm{EV}$ and effective composting, it is expected that $\mathrm{CO} 2$ emissions would be curbed by 600,000 tCO2e within Ontario by 2050, a $75 \%$ reduction from current projected emissions.

\section{Addressing climate change with renewable energy}

Aryan Alidad, B.Eng Student [1], Andrew Rodenburg, B.Eng Student [2] Hans Park, B.Eng Student [2]

[1] Department of Chemical Engineering, McMaster University, Hamilton, Ontario, Canada

[2] Department of Mechanical Engineering, Hamilton, Ontario, Canada

With the gap between renewable energy and consumption growing simultaneously with energy security concerns, efforts are being made in order to diminish the environmental impact of conventional fuels and implement sustainable systems. This proposal aims to decrease waste emissions of the city by diverting organic material and sewage treatment sludge into a CHP system which will be attached to a city's new thermal grid for municipal buildings and process of electrolysis to procure hydrogen and inject this hydrogen into the local natural gas system will further lower emissions of the city for anything using natural gas, likely furnaces. Excess renewable electricity on the grid can be converted to hydrogen gas via electrolysis at a high efficiency. The hydrogen can then be injected into the natural gas system, providing a fuel blend that is up to $18 \%$ cleaner than regular natural gas. Many government policies can also be enacted to greatly reduce gas demand.

Driving change: Reducing $\mathrm{CO}_{2}$ emissions in an urban city Ma'Moon Ayesh, B.Eng Student, Janderic Del Rosario, B.Eng.Mgmt Student [1], Jillian Ma, B.Eng Student [2], Khadin Nathoo, B.Eng Student [2], Travis Sagar, B.Eng.Mgmt Student [3]

[1] Department of Mechanical Engineering, McMaster University, Hamilton, Ontario, Canada L8S 4L8

[2] Department of Chemical and Bioengineering, McMaster University, Hamilton, Ontario, Canada L8S 4L8

[3] Department of Civil Engineering, McMaster University, Hamilton, Ontario, Canada L8S 4L8

Urban cities around Canada and the world are experiencing extreme levels of $\mathrm{CO}_{2}$ emissions caused by the millions of vehicles on the roads. Currently, car companies are producing electric vehicles which have begun to spike in popularity and importance. Government policies and interventions can help stimulate positive changes in the transportation sector to make large decreases in $\mathrm{CO}_{2}$ emissions. Waiting for people to make these decisions on their own would result in minimal improvement, nor does it solve issues with overpacked roads. By creating policy to ban several cars from entering the downtown core, we can eliminate congestion and small trips to several locations which have a tremendous compounding effect. $40 \%$ of all combustion engine commuter vehicles can be trimmed down by encouraging carpooling, electric vehicles and most importantly, public transportation within one year, and even greater reduction in future years. Extensive public transportation coverage and driving alternatives such as bike sharing, and delivery services are essential in reducing the effect of transportation on our environment. This also allows for more efficient "road diets" and reduced land masses lost to parking. 
UNDERGRADUATE RESEARCH IN NATURAL AND CLINICAL SCIENCE AND TECHNOLOGY (URNCST) JOURNAL Read more URNCST Journal articles and submit your own today at: https://www.urncst.com

Bringing the electric grid into the 2020s

Alexander Barovier, B.Eng Student [1], Julia Bauer, B.Eng Student [2], Connor Chandran, B.Eng.Mgmt Student [3], Kierra McDougall, B.Eng Student [2] - Rachel McKenzie, B.Eng Student [2]

[1] Department of Engineering Physics, McMaster University, Hamilton, Ontario, Canada

[2] Department of Integrated Biomedical Engineering \& Health Sciences, Hamilton, Ontario, Canada

[3] Department of Electrical Engineering, Hamilton, Ontario, Canada

For Canada to reach their future climate change goals, a robust grid infrastructure system for efficient energy transportation is essential. We currently rely on several forms of energy for daily function and societal progression. Whether the energy source is from our electric grid or from the combustion of hydrocarbons, we always meet energy requirements with ease. However, harmful by-products of hydrocarbon combustion release tonnes of greenhouse gases, ultimately resulting in climate change. Global communities have outlined climate change goals to significantly reduce greenhouse gas emissions. To help society achieve these goals, Solar Saltutions have developed several strategies that are technologically, socially, and economically feasible to combat climate change. The main sector we will focus on is improving the grid infrastructure. The implementation of our energy solution includes different technological processes for tackling the varying demand for electricity. The Integral Molten Salt Reactors produce a fixed amount of electricity, which can be used to heat homes and run industrial processes that require heat. The Sonnen smart grid is also explored, with solar producing electricity and storage in batteries. Additionally, electrification of transportation and changes to grid infrastructure is tackled to compensate for the increase in demand for electricity.

Vision of an ideal smart community

Jasleen Deol, B.Eng.Mgmt [1]Ankur Verma, B.Eng.Mgmt Student [2], Abijith Mani, B.Eng Student [2], Sahaj Singh, B.Eng Student [2], Paramveer Nihal, B.Eng Student [2]

[1] Department of Computer Engineering, McMaster University, Hamilton, Ontario, Canada

[2] Department of Electrical Engineering, McMaster University, Hamilton, Ontario, Canada

The purpose of this report is to implement a solution which addresses the growing concern of greenhouse gas emissions and energy consumption. Through extensive research, we have provided several solutions that target different areas within residential real estate such as lighting, heating, and overall energy consumption. Our ideal implementations include solar energy, mirror lighting and smart grid technologies, all of which contribute to a more sustainable home and in term, the Ideal Smart Community.

A circular economy: Addressing an approach to reducing Canada's greenhouse gas emissions Leisha Fernando, B.Eng Student [1], Tanishq Gupta, B.Eng Student [2] Rayan Hussain, B.Eng Student [2], Azeem Shah, B.Eng Student [2], Valentina Villate, B.Comm Student [3]

[1] Department of Civil Engineering, McMaster University, Hamilton, Ontario, Canada

[2] Department of Electrical Engineering, McMaster University, Hamilton, Ontario, Canada

[3] Department of Commerce, McMaster University, Hamilton, Ontario, Canada

Raising awareness and educating the population is a key step towards achieving sustainability in a society. Many of the ways in which GHG emissions can be reduced is to have a optimal waste management system in which little to no harmful waste is produced in the society. Utilizing the waste to produce energy is also a crucial step in achieving low GHG emissions.

Utilization of algae and methanotrophs in the reduction of greenhouse gases Gayle Menezes, B.A.Sc Student [1], Imaan Walji B.A. Student [2], Maraam Haque, B.Sc Student [1], Navodi Athapaththu, B.Eng Student [3], Zahra Syed, B.Eng Student [3]

[1] Department of Psychology, Neuroscience \& Behaviour, McMaster University, Hamilton, Ontario, Canada

[2] Department of Political Science, McMaster University, Hamilton, Ontario, Canada

[3] Department of Electrical Engineering, McMaster University, Hamilton, Ontario, Canada

This paper proposes to utilize organisms such as algae and methanotrophs in bioreactor facilities to mitigate greenhouse gas emissions. The basic concept and design of such facilities is discussed, and their impact on different industry sectors (e.g. the waste management sector, grid infrastructure, agriculture, transportation and residential buildings) is explored. The report finds 
UNDERGRADUATE RESEARCH IN NATURAL AND CLINICAL SCIENCE AND TECHNOLOGY (URNCST) JOURNAL Read more URNCST Journal articles and submit your own today at: https://www.urncst.com

that natural organisms that consume greenhouse gases as part of their natural diet can be employed to significantly reduce a community's impact on the environment and global warming.

Shifts toward sustainable, densely populated cities

Yang Hu, B.Sc Student [1], Alicia Tran, B.Eng Student [2], Yina Shan, B.HSc Student [3], Keith Onderisin, B.Tech Student

[1] Department of Kinesiology, McMaster University, Hamilton, Ontario, Canada

[2] Department of Integrated Biomedical Engineering \& Health Sciences, McMaster University, Hamilton, Ontario, Canada

[3] Department of Health Science, McMaster University, Hamilton, Ontario, Canada

With the rising population and resultant greenhouse gas emissions adding pressure to urban transportation and agricultural systems - new economic policies, lifestyle changes, built infrastructure, and agricultural systems are critical to move toward a healthier and more sustainable future. A modal shift from personal vehicles toward active and public forms of transportation, which requires infrastructural, policy-based, economic, and community support, will reduce emissions and improve population health. Concurrently, a shift towards electric vehicles will significantly reduce the carbon emissions caused by transportation. The increased usage of these vehicles provide an opportunity to adopt a vehicle-to-grid system to better assist with electricity demand. With the rising population, the environmental imprint left by the agricultural sector continues to grow. It is therefore essential to begin placing the emphasis on effective and viable ways to reduce GHG emissions by focusing on lifestyle changes that can be adopted by consumers, such as shifting from meat-heavy to plant-based diets. To facilitate this shift, vertical farming presents an exciting opportunity to cultivate fresh produce without the need for arable land, in which many growing factors can be controlled to optimize the growth of fruits and vegetables. Though it is a technology in its infancy, vertical farming connects fresh produce directly to consumers within urban centres.

Energy optimization in wastewater treatment process

Jelena Dong, B.Eng Student [1], Yunxi He, B.Eng Student [1] Ray Hoyos, B.Eng Student [1] Shirley Liu, B.Eng Student [1], Zhi Zheng, B.Eng Student [1]

[1] Department of Civil Engineering, McMaster University, Hamilton, Ontario, Canada

Climate change, especially GHG emissions, is something the governments continue to address and try to tackle. To accomplish the great goal of reducing GHG emissions globally, it is crucial to act locally. This proposal focuses on a projected community of 200,000 people, with an emphasis on reducing wastewater going into the wastewater treatment plant by redirecting it to hybrid constructed wetlands. When passing through the hybrid constructed wetlands, the total suspended solids and pollutants can be eliminated. After calculation, a population of 200,000 can result in $1.468 \mathrm{e}-3$ Mt annual GHG emission, while the proposed wetlands only produce 5.211 ton per year. Before sewage water enters the wetlands, it goes through the microbial cells to generate electricity. Based on an assumed area of $3000 \mathrm{~m}^{2}$ covered at a population of 200,000 , it would save $25740 \mathrm{kWh}$ of electricity. Based on these predictions, the proposal would lead to lower GHG emissions while optimizing electricity generation.

\section{Conflicts of Interest}

The authors declare that they have no conflict of interests.

\section{Authors' Contributions}

HC: Founder and Chair of the $1^{\text {st }}$ annual McMaster Energy Week.

RR: Served as Case Competition Lead, developing the case and aiding delegates in the development of their case proposals and abstracts.

DJ: Served as VP Education, drafted the competition book and reviewed abstract submissions.

FO: Served as Competition Co-Coordinator

MA: Served as Competition Co-Coordinator

\section{Acknowledgements}

Special thanks to our graduate student mentors, whose guidance and wisdom was integral in the success of the development of the case proposals and the competition as a whole. We would like to also thank the judging panel for their time and critical appraisal on the day of the competition. 
UNDERGRADUATE RESEARCH IN NATURAL AND CLINICAL SCIENCE AND TECHNOLOGY (URNCST) JOURNAL Read more URNCST Journal articles and submit your own today at: https://www.urncst.com

\section{Funding}

We would like to thank our generous sponsors for their financial support for McMaster Energy Week: Alectra, McMaster Faculty of Engineering, Thrillhouse Studios, McMaster Science Initiative Fund, HCE Energy Inc., Ontario Power Generation, Blackstone Energy Services, Ontario Climate Consortium, Sidewalk Labs, Canada’s Energy Citizen’s, MIES.

\section{Article Information}

Managing Editor: Jeremy Y. Ng

Article Dates: Received Mar 05 19; Published Mar 0819

\section{Citation}

Please cite this article as follows:

Joseph D, Chaudhari H, Rogers R, Ologunagba F, Ahmed M. The 2nd annual McMaster Energy Week: Energy Nexus Competition. URNCST Journal. 2019 Mar 08: 3(3). https://urncst.com/index.php/urncst/article/view/139

DOI Link: https://doi.org/10.26685/urncst.139

\section{Copyright}

(C) Damien Joseph, Hanu Chaudhari, Ryan Rogers, Folarin Ologunagba, Maisha Ahmed. (2019). Published first in the Undergraduate Research in Natural and Clinical Science and Technology (URNCST) Journal. This is an open access article distributed under the terms of the Creative Commons Attribution License (https://creativecommons.org/licenses/by/4.0/), which permits unrestricted use, distribution, and reproduction in any medium, provided the original work, first published in the Undergraduate Research in Natural and Clinical Science and Technology (URNCST) Journal, is properly cited. The complete bibliographic information, a link to the original publication on http://www.urncst.com, as well as this copyright and license information must be included.

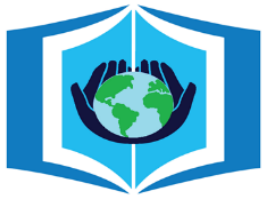

\section{URNCST Journal}

"Research in Earnest"

\section{Funded by the Government of Canada}

\section{Canadà̀}

Do you research in earnest? Submit your next undergraduate research article to the URNCST Journal!

| Open Access | Peer-Reviewed | Rapid Turnaround Time | International | | Broad and Multidisciplinary | Indexed | Innovative | Social Media Promoted |

Pre-submission inquiries? Send us an email at info@urncst.com | Facebook, Twitter and LinkedIn: @URNCST

Submit YOUR manuscript today at https://www.urncst.com! 